\section{Effectiveness of motivational interviewing in smoking groups in primary healthcare: a community-based randomized cluster trial}

\author{
A efetividade da entrevista motivacional em \\ grupos de tabagistas na atenção primária: um \\ estudo randomizado de clusters comunitários
}

\section{Efectividad de las entrevistas motivacionales en grupos de fumadores dentro de la atención primaria: un ensayo grupal aleatorio basado en comunidades}

Ricardo Melnick 1

Claunara Schilling Mendonça 1

Elisabeth Meyer 2

Daniel Demétrio Faustino-Silva 1

\begin{abstract}
Smoking is the main cause of avoidable death and a major public health problem worldwide, with primary healthcare being a strategic setting for treating this problem. Aims: to evaluate the effectiveness of motivational interviewing associated with the cognitive behavioral therapy (CBT) in smoking groups in primary healthcare. A community-based cluster randomized clinical trial was conducted in Brazil, starting in July 2016. Professionals in the test group were trained in motivational interviewing for eight hours to associate it with the CBT. The usual treatment for smoking cessation in groups consists of four structured weekly sessions of 90 minutes each using a CBT. Taylor's linearization was used to correct the p-values; the chi-square test with Pearson correlation was used for categorical variables, and analysis of variance as well as the Student t-test were used for continuous variables. In total, 44 smoking groups were conducted, totaling 329 patients (178 in the motivational interviewing group and 151 in the control group). The smoking cessation rate with motivational interviewing was $61.8 \%$, with $R R=1.25$ (95\% CI: $1.01-1.54, p=$ 0.043), and $47.7 \%$ in the control group, in the fourth weekly group treatment session. Mean session attendance was 3.1 (95\% CI: 2.9-3.3) in the motivational interviewing group and 2.9 (95\%CI: 2.5-3.4) in the control group. The completion rate for the motivational interviewing group was $65.2 \%$ and for the control group, 57.6\%. Motivational interviewing associated with the CBT was shown to be effective and superior to only CBT to smoking cessation in groups in the fourth weekly session and for the population profile of the study (women with an average age of 50.6 years).
\end{abstract}

Smoking; Motivational Interviewing; Smoking Cessation; Primary Health Care; Biomedical Technology Assessment

\author{
Correspondence \\ D. D. Faustino-Silva \\ Grupo Hospitalar Conceição. \\ Av. Francisco Trein 592, Porto Alegre, RS 91350-200, Brasil \\ ddemetrio@gmail.com \\ 1 Grupo Hospitalar Conceição, Porto Alegre, Brasil. \\ 2 Instituto de Cardiologia do Rio Grande do Sul, Fundação \\ Universitária de Cardiologia, Porto Alegre, Brasil.
}




\section{Introduction}

Smoking is a serious public health problem and the leading cause of avoidable death, accounting for six million deaths a year worldwide and significant economic losses 1. It is directly associated with chronic non-communicable diseases (NCDs), accounting for 68\% of 56 million deaths worldwide in 2012 2, and in Brazil, 72\% of deaths in 2007 3. The prevalence of smoking in Brazilian capitals in 2013 was $11.3 \% 4$ and it has not been significantly reduced over the years ${ }^{5}$. Despite the advances, data from 2008 attribute to cigarettes a cost of BRL 20.68 billion and 13\% of deaths in Brazil, reducing life expectancy by 5 years 6 . Although the country is the second largest tobacco producer and exporter and it has made significant efforts for its control - reducing the number of smokers - there are still major challenges ${ }^{7}$. The great magnitude of smoking indicates a need to develop and to evaluate new technologies for the treatment of this serious problem within the scope of the Brazilian Unified National Health System (SUS).

Primary health care (PHC) is a key strategic setting for coping with this epidemic within SUS by offering comprehensive longitudinal care, close to the user, favoring the establishment of a bond 6 . The International Primary Care Respiratory Group (IPCRG) has recently reinforced this position, since in many countries it is the only sector with access to this support, with better results, prevention, and user's satisfaction 8 . Since 1989, the Brazilian National Cancer Institute (INCA) has been coordinating the actions of the Brazilian Smoking Control Program (Programa Nacional de Controle do Tabagismo - PNCT), defining treatment with a cognitive behavioral approach in structured groups 7,9. In line with the PNCT, the Community Health Service, Conceição Hospital Group (SSC-GHC) implemented in 2005 a specific programmatic action, training their professionals, initially in only 4 teams. Since 2011 they have put together smoking groups in their 12 health care units, and this program is regarded as an indicator for management goals 10 . More intensive approaches - longer than ten minutes - are more indicated whenever feasible, ideally in the form of structured groups, in 4 weekly 90 minute-long sessions, as advocated by INCA 7,9,11. Motivation can be one of the factors involved in the smoking cessation process and, paradoxically, one of the main obstacles for the health team 6 . Some evidence suggests that the identification of the motivational stage is extremely significant in the formulation of interventions, and it should be appropriate to the person's context, considering their singularities and ambivalences 6,12,13, and it should also considers adverse health conditions as the main predictors of change 14 .

Motivational interviewing has been shown to be quite effective for behavioral changes, and when focusing on nicotine-dependent patients, it has great potential for coping with their inherent ambivalence, fears, and conflicts 12 . Motivational interviewing is a type of person-centered clinical approach whose goal is to work on and to enhance the user's motivation for behavioral change, usually related to lifestyle habits, dysfunctional behaviors, and adherence to treatments 15 . This approach is especially employed to deal with ambivalence, usually present in addictive behaviors, in a more persuasive than coercive way 16. It was first developed by Miller and Rollnick in 1983, as a brief intervention for alcohol abuse. Noting that lectures, arguments, and warnings did not work with ambivalent people, they realized that a different, softer method was necessary, using concord to tap into this feeling, which is not exclusive to addictive behaviors, but inherent in the human condition 15.

In a recent review of studies on strategies for the management of smoking in PHC, the authors highlight: individual approach, medicine prescription, monitoring with the aid of electronic devices, and intervention in groups 17. Therefore, smoking groups are viable tools for PHC and with results around $51 \%$ of abstinence in the Brazilian context $18,19,20$. In this sense, it is necessary to evaluate approaches that can increase these smoking cessation rates in PHC.

The main objective of this study was to evaluate the effectiveness of motivational interviewing associated with the cognitive behavioral therapy in smoking groups in primary healthcare, comparing it with the cognitive behavioral therapy. Furthermore, it intended to verify the treatment completion rate for patients in groups of smokers in the fourth weekly session. 


\section{Methods}

A community-based cluster randomized clinical trial was carried out at the 12 health care units (HCU) that composed the SSC-GHC, located in the Northern area of Porto Alegre, Rio Grande do Sul State, Brazil. This service - which is recognized for its strong association with the quality of primary care - has been carrying out care and learning activities for more than 30 years, pioneering the training of family physicians in Brazil, as well as other professionals. It characteristically works with programmatic actions and since 2005 has been organizing groups of smokers in its centers.

The usual treatment for smoking cessation in groups consists of four structured weekly sessions of 90 minutes each using a cognitive behavioral approach. Drug treatment can be used according to the patient's indication and clinical evaluation. Nicotine replacement therapy-NRT (transdermal patch) and bupropion are available. As a condition to coordinate smoking groups, all professionals must necessarily undertake training in cognitive behavioral therapy (CBT) lasting 16 hours and recommended by the Brazilian Ministry of Health.

\section{Universe and sampling}

The study population was composed of adult smokers from the SSC-GHC coverage area, and the sample included all individuals from the smoking groups organized in all 12 SSC-GHC centers from July 2016 to the end of May 2017. There were no criteria for exclusion of participants. Patients were referred by doctors or other professionals on the PHC team.

We relied on the results of the SSC-GHC anti-tobacco program in the years 2014 and 2015 in order to estimate the sample size. In the first year mentioned, 45 groups were put together, totaling 326 patients, with 167 reporting quitting smoking at the end of the meetings, resulting in a cessation rate of 51\% 19. In 2015, 43 groups were organized, with 329 patients. Out of these, 168 resulted in abstinence, accounting for a total smoking cessation rate of $51 \% 20$.

It was estimated that in order to increase cessation rates by $20 \%$ among the participants of the SSC smoking groups, including motivational interviewing, considering a 5\% significance level and a statistical power of $80 \%$, the sample should include 206 patients, divided by half for each study group.

\section{Randomization and blinding}

To avoid contamination between groups (professionals and patients), randomization was performed per health care unit (cluster), using a random number table generated on a computer by one researcher, accompanied by two external witnesses to the study. The professionals at each health care unit used the same intervention for all patients. This way, if the patients talked or shared ideas with one another in the waiting room or even with relatives and neighbors about the approach used, there would be no biases as they were all in the same group. Patients could only seek treatment at the healthy care unit to which they were registered. Participants were recruited after randomization of health care units. Therefore, it was not possible to maintain the allocation concealment.

Blinding was impossible because of the behavioral nature of the intervention.

\section{Study groups}

- Test group: motivational interviewing associated with cognitive behavioral therapy in groups. In this group, composed of six randomized health care unit, the professionals who coordinated the smoking groups received training in motivational interviewing, with the purpose to apply the proposed technique as an additional resource to the motivation effort and the CBT.

- Control group: cognitive behavioral therapy in groups. In this group, composed of the remaining six randomized health care unit, the professionals used only the traditional cognitive behavioral approach. 


\section{Test intervention - motivational interviewing training}

The test intervention under study was the training in motivational interviewing and its effect on smoking groups. To provide training, a specialist in motivational interviewing - who had been trained in the United States by the approach creators, Miller \& Rollnick 21, - was invited, in addition to the participation of service staff who had already undertaken training on other occasions. The total workload was eight hours, divided into two four-hour shifts, in June 2016, starting at 8:00a.m. and ending at noon, and then from 2:00p.m. to 6:00p.m., on the same days, to include the afternoon shift workers. This way, all professionals had access to the same training.

Training provided knowledge of theory, spirit, basic principles, and strategies used in motivational interviewing. There was an emphasis on the understanding of the conceptual framework of motivational interviewing based on available evidence on the effectiveness of this training 22 . The focus was to use motivational interviewing skills to stimulate people to persuade themselves that a change was necessary, considering the spirit of motivational interviewing 15,21,22. Training is delivered in an experiential format, with practical guidelines for topics such as: use of empathic communication skills, use of simple and advanced reflection to work on resistance and ambivalence, development of discrepancy, listening, and eliciting a "conversation about change". These contents are presented by a combination of lectures, case studies, videos, and exercises in pairs and in small groups. At the end, attendees receive a sheet containing instruments that will allow them to observe if they have mastered the basic skills specific to motivational interviewing.

Once training has been completed, attendees are expected to be able to:

(a) Recognize and use the components of motivational interviewing;

(b) Recognize and employ different types of reflection;

(c) Identify techniques to "monitor" resistance;

(d) Describe techniques to explore patient discrepancy;

(e) Recognize and use techniques to elicit a "conversation about change".

In the motivational interviewing training, the following materials were used:

(1) Importance and confidence ruler: suggested by Miller \& Rollnick 21, this is a visual analogue method of rating on a scale from 0 to 10, the following dimensions: A - Importance (how important is it for you to use motivational interviewing?) B - Confidence/Self-efficiency (how confident would you say you are that you could be successful if you decided to use motivational interviewing in your appointments?)

(2) Conversational interview exercise 21: before the beginning of the training session and at the end, the attendee receives a sheet containing the same conversational interview where they must identify the key elements of motivational interviewing, such as the use of reflections and open-ended questions.

(3) Helpful Responses Questionnaire (HRQ) - Miller et al. 24, developed this six-item questionnaire to evaluate the extent to which participants use reflective listening before and after training. The HRQ presents 6 hypothetical patient statements and asks the respondent to write "what they would say next" in response to each statement. Each answer is classified by the presence or absence of openended and closed-ended questions, reflections, and "conversations that make change difficult". The total scores are the sum per category of answers (maximum score $=6$ ). Moreover, each answer is rated from 1 to 5 , using a scoring algorithm whereby high scores are given to answers that are accurate in empathy and absence of "conversations that make change difficult", whereas low scores indicate either lack of reflective listening or that the reflective quality is diminished by "conversations that make change difficult". The score for deep reflection is determined by the sum of answer scores (maximum score $=30$ ).

\section{Instruments and outcomes}

The variables used were the number of groups held at each center, the number of patients attending at least one meeting of the group, the number of people attending the fourth and last weekly session, and, among these, the number of patients who were not smoking anymore at the time. The main outcome, smoking abstinence, was recorded by the patient's self-report. No biochemical verification 
was performed. Participants who did not attend the last group session were considered to be smokers. The Fagerström test 9 score (whose role is to measure and assess the degree of nicotine dependency, establishing a score from 0 to 10 ) was also used, in addition to the number of patients who used nicotine patch and bupropion.

These data were extracted from the information system of the SSC-GHC anti-tobacco program, made available by the monitoring and evaluation division of the service. The program, in turn, follows the records as recommended by INCA and the municipal management coordinator for NCDs. The center staff is responsible for supplying the system with these data, every time a group session is held.

\section{Data processing and analysis}

In 2017, the construction and analysis of the database and the interpretation of the results were accomplished using the software SPSS, version 18.0 (https://www.ibm.com/), and Stata (https:// www.stata.com), for cluster analysis. The continuous variables were described as means and confidence interval. The categorical variables were expressed as absolute and relative frequencies. Relative risk (RR) was calculated as an effect measure, with a $95 \%$ confidence interval (95\%CI) to estimate the increase in smoking cessation rates in the groups. The descriptive analyses were based on the survey commands to account for the clustering effect of sampling. Taylor's linearization was applied to correct the p-values; the chi-square test with Pearson correlation was used for categorical variables and analysis of variance and the Student $t$-test were used for continuous variables. For multivariate analysis and control of intervening factors, the robust Poisson regression method was used for all variables, except for the variable attendance at the fourth session, as it presented multicollinearity with the variable number of sessions.

\section{Ethic aspects}

The study project was submitted to and approved by the GHC Research Ethics Committee under the CEP n.: 16-101 and Plataforma Brasil CAAE: n. 56902516.4.0000.5530 as it was in accordance with the national, international, and complementary guidelines and norms, especially resolution 466/12. This clinical trial was registered at ClinicalTrial.gov (NCT03221010). Registered 16 July 2017 - Retrospectively registered.

\section{Results}

From July 2016 and May 2017, 44 smoking groups were organized by the SSC teams, totaling 329 participants analyzed in the study. A total of 21 control groups were created, with a total of 151 patients (7.2 participants per group, on average). There were 23 intervention groups, with a total of 178 patients ( 7.7 participants per group, on average).

Figure 1 shows the study flowchart.

Participant characteristics per group are shown in Table 1. The overall mean age was 50.6 years (95\%CI: 49.1-52.1). There was no variation between the study groups. In the control group, the mean age was 50 years (95\%CI: 47.9-52.1), and in the intervention group, 51.1 years (95\%CI: 49.1-53.2). The female sex prevailed, and in the groups under study, it accounted for $69.5 \%$ of the patients, while males were $30.5 \%$, without significant differences in the two groups (68\% in the control group and $70.8 \%$ in the intervention group).

The clinical characteristics available in the system, such as the Fagerström score, had an overall mean of 6.4 (95\%CI: 5.8-6.9). The distribution of this variable was homogeneous among groups (Table 1).

Table 2 shows the outcomes and variables related to anti-tobacco treatment in each group during the study period. The primary outcome, total number of participants that quit smoking at the end of treatment, in the 12 SSC-GHC health care units, was 182 (55.3\%). The group using motivational interviewing achieved $61.8 \%$ of abstinence (110 patients), whereas the control group, $47.7 \%$ ( 72 patients), in the fourth weekly group treatment session. The mean number of participants attending the sessions did not differ significantly between groups, 3.1 (95\%CI: 2.9-3.3) in the intervention group and 2.9 


\section{Figura 1}

Flowchart for randomization, assignment, and analyses of study participants (Consolidated Standards of Reporting Trials CONSORT, 2010).

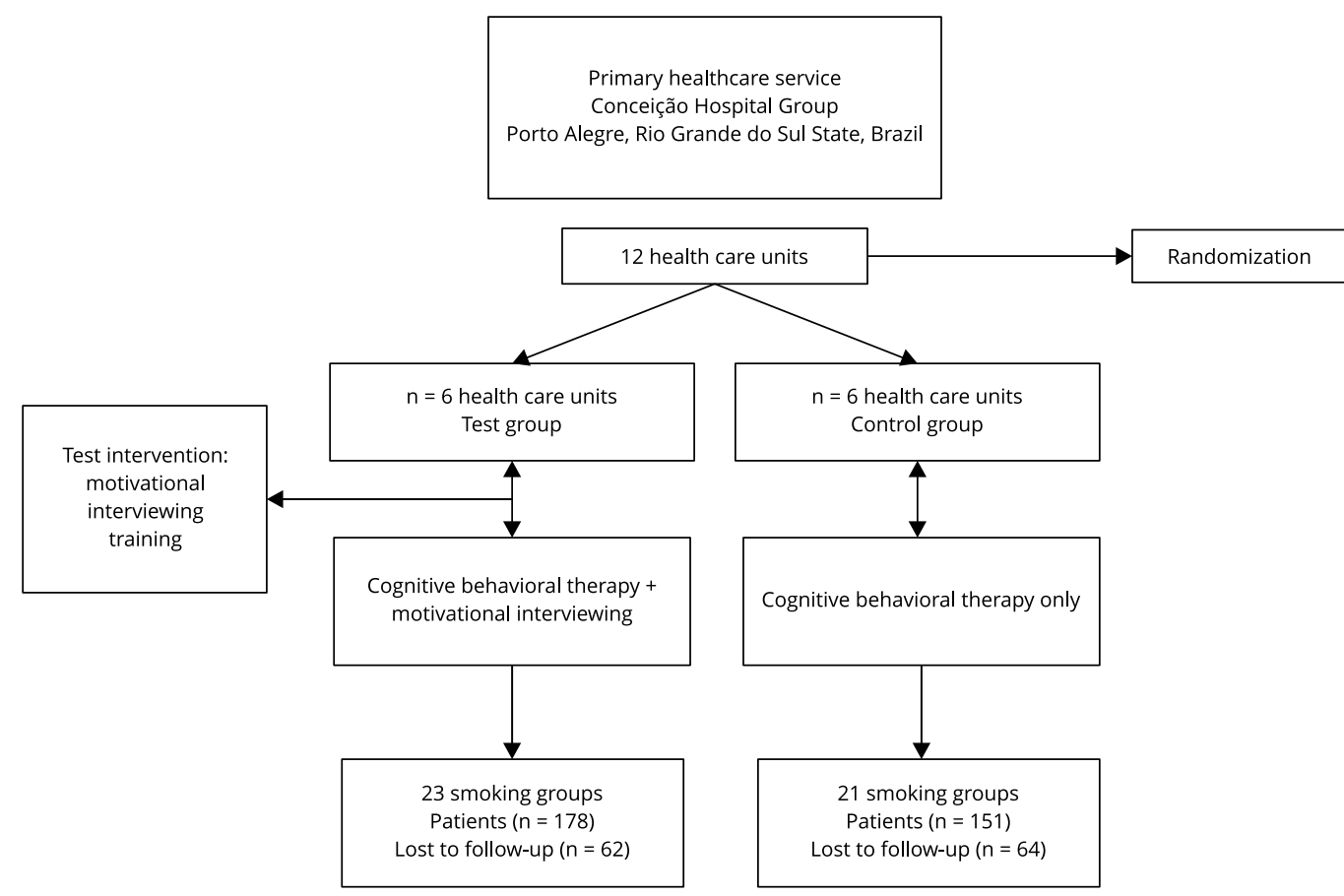

Table 1

Characteristics of patients submitted to anti-tobacco treatment per group. Porto Alegre, Rio Grande do Sul State, Brazil, 2017.

\begin{tabular}{lcccc}
\hline Characteristic & Total & $\begin{array}{c}\text { Test group } \\
\text { (motivacional } \\
\text { interviewing + CBT) }\end{array}$ & $\begin{array}{c}\text { Control group } \\
\text { (CBT) }\end{array}$ & p-value \\
\hline $\mathrm{n}$ & 329 & 178 & 151 & $0.398 *$ \\
Age & $50.6(49.1-52.1)$ & $51.1(49.1-53.2)$ & $50.0(47.9-52.1)$ & $102(68.0)$ \\
Female sex & $228(69.5)$ & $126(70.8)$ & $6.4(5.9-7.0)$ & $0.935 *$ \\
Fagerström test & $6.4(5.8-6.9)$ & $6.4(5.5-7.3)$ & 6.4 \\
\hline
\end{tabular}

95\% Cl: 95\% confidence interval; CBT: congnitive behavioral therapy.

* The values shown are the mean and $95 \% \mathrm{Cl}$, the comparison uses the Student t-test;

** The values shown are absolute and relative frequencies, the comparison uses the chi-square test. 
(95\%CI: 2.5-3.4) in the control group. The total number of people attending the fourth session and who consequently completed the treatment was 203 (61.7\%). Between groups, the rate was higher in the intervention group, 65.2\%, while in the control group it was 57.6\%. Most of them had an individual appointment for clinical assessment (which is part of the program), 79.8\% in the intervention group and $88.7 \%$ in the control group. Most patients in all groups also used medicine. Most of the time, a nicotine patch was used as adjuvant therapy, $71.9 \%$ in the intervention group and $68.9 \%$ in the control group, which showed the homogeneity of this drug treatment in both comparison groups (Table 2).

In the multivariate analysis using a robust Poisson regression model, shown in Table 3, the variables from the information system of the SSC anti-tobacco program, sex, age, Fagerström test, clinical assessment, visit attendance, number of sessions, prescription of nicotine patch and bupropion, were associated. The results showed an RR $=1.25$ (95\%CI: 1.01-1.54; $\mathrm{p}=0.043$ ) for smoking cessation in the training group that used motivational interviewing, which was the main outcome under study, showing a statistically significant association of the intervention with an increase in smoking cessation rates. The Fagerström test, a predictor of this dependence intensity, showed an RR = 0.93 (95\%CI: 0.89-0.98; $\mathrm{p}=0.006$ ). For the number of sessions, the RR was 1.53 (95\%CI: 1.19-1.97; $\mathrm{p}=0.004$ ).

\section{Table 2}

Description of variables related to anti-tobacco treatment per participant's group. Porto Alegre, Rio Grande do Sul State, Brazil, 2017.

\begin{tabular}{lccc}
\hline Characteristic & $\begin{array}{c}\text { Test group } \\
\text { (motivacional } \\
\text { interviewing + CBT) }\end{array}$ & $\begin{array}{c}\text { Control group } \\
\text { (CBT) }\end{array}$ & p-value \\
\hline $\mathrm{n}$ & 178 & 151 & 0.514 * \\
Number of sessions & $3.1(2.9-3.3)$ & $134(88.7)$ & 0.354 ** \\
Had an individual clinical appointment & $142(79.8)$ & $104(68.9)$ & 0.712 ** \\
Used a patch & $128(71.9)$ & $27(17.9)$ & $0.307 * *$ \\
Used bupropion & $48(27.0)$ & $87(57.6)$ & 0.409 ** \\
Attended the 4th session & $116(65.2)$ & $72(47.7)$ & $0.157 * *$ \\
Quit smoking at the 4th session & $110(61.8)$ & & \\
\hline
\end{tabular}

95\% Cl: 95\% confidence interval; CBT: congnitive behavioral therapy.

* The values shown are the mean and $95 \% \mathrm{Cl}$, the comparison uses the Student t-test;

** The values shown are absolute and relative frequencies, the comparison uses the chi-square test.

Table 3

Multivariate analysis. Adjusted relative risk and 95\% confidence interval (95\% Cl) for the outcome under study. Porto Alegre, Rio Grande do Sul State, Brazil, 2017.

\begin{tabular}{|c|c|c|c|}
\hline Characteristic & $\mathbf{R} \mathbf{R}$ * & $95 \% \mathrm{Cl}$ & p-value \\
\hline Quit smoking in the test group (motivacional interviewing + CBT) & 1.25 & $1.01-1.54$ & 0.043 \\
\hline Age & 1.00 & $0.99-1.01$ & 0.354 \\
\hline Female sex & 0.97 & $0.81-1.17$ & 0.764 \\
\hline Fagerström test & 0.93 & $0.89-0.98$ & 0.006 \\
\hline Number of sessions & 1.53 & $1.19-1.97$ & 0.004 \\
\hline Had an individual clinical appointment & 1.22 & $0.92-1.61$ & 0.150 \\
\hline Used a patch & 1.99 & $0.93-4.25$ & 0.073 \\
\hline Used bupropion & 1.06 & $0.86-1.31$ & 0.539 \\
\hline
\end{tabular}

CBT: cognitive behavioral therapy; RR: relative risk.

* Calculated using robust Poisson regression. 
Regarding drug therapies, the use of nicotine patch had an $R R=1.99(95 \%$ CI: $0.93-4.25 ; p=0.073)$ and bupropion, $\mathrm{RR}=1.06$ (95\%CI: 0.86-1.31; $\mathrm{p}=0.539$ ), but there was no statistical significance. Attending an individual appointment (clinical assessment) resulted in an $\mathrm{RR}=1.22$ (95\%CI: 0.92-1.61; $\mathrm{p}=$ 0.150). Age and sex did not show any association with statistically significant differences (Table 3 ).

The number needed to treat (NNT) was 7.1, which means that, on average, 7.1 patients need to be treated with motivational interviewing associated with CBT, so that one will quit smoking.

\section{Discussion}

The study showed a statistically significant increase in smoking cessation rates following the training of professionals to use motivational interviewing: RR $=1.25$ (95\%CI: 1.01-1.54; $\mathrm{p}=0.043$ ), that is, the intervention increased smoking cessation by $25 \%$ in the group test. The literature shows similar results in meta-analyses 25 ( $R R=1.24 ; 95 \% \mathrm{CI}$ : $0.91-1.69)$ but in very different situations, which should be interpreted with caution due to variations in the quality and heterogeneity of the studies. The authors of this systematic review conclude that the evidence is insufficient to state that motivational interviewing helps people to stop smoking either when used alone or associated with other types of behavioral approaches. It is also unclear how much the intensity of the motivational approach improves results and what future studies may change these findings 25 . A recent clinical trial also indicated its superiority in comparison with the brief approach 26 . Generally, previous studies and meta-analyses on the effect of motivational interviewing on smoking have compared it to short approaches, with different methodologies and in very diverse groups 27,28 , demonstrating its superiority, although more intensive approaches are said to be able to produce better results, whereas this study tested - although for a short time (immediate results in the fourth session of the smoking groups) - two intensive approaches within the same service, in the specific setting of primary care. This can be a significant contribution to the understanding and assessment of the use of this approach in our context, which can be added to the other evidence available. By demonstrating the superiority of its specific use in smoking groups and within primary care, this study may signal an innovation for the assessment and proposed use of this approach.

The treatment completion rate in the groups, defined as attendance at the fourth session, as well as the mean number of patients attending the sessions, was also higher in the intervention group, although no significant difference was shown between the groups. This finding assures a discussion about adherence. The literature on motivational interviewing in different primary care situations indicate that his technique tends to enhance adherence 29 . Other sources assert that trials have shown that patients exposed to motivationao interviewing have been considered to be more likely to start, keep, and complete treatments 15,30 .

A factor that corroborates the validity of the study is the observation that clinical variables, such as the Fagerström test, the main predictor for the degree of dependence and difficulty of cessation 7,9, were homogeneous in both groups, showing that there was no predominance of more severe smokers in one of the groups. Another factor, the number of groups organized in the service 19,20, as well as the number of participants, was shown to be homogeneous. Therefore, there were no significant changes or exceptional facts in the study period that might have interfered as a bias in this respect. The service coordination remained the same, and there were not many changes to the teams coordinating the groups.

Regarding the use of medications, there were more prescriptions for nicotine patch than for bupropion. The literature indicates that both methods are effective and enhance cessation rates 7,9,11; however, they are merely aids to the process. Cognitive-behavioral and motivational approach are the basis of the treatment, and the pharmacological measures do not influence motivation, but rather the symptoms related to physical dependence and abstinence.

With respect to the profile of the smokers who participated, most were women (69.5\%), contrasting with data showing a higher frequency of smokers among men 4,5,7. This is probably because, in primary care, the participation of women is usually far higher, as they typically care more about their health. The lower level of demand for care among men is notable. These questions may indicate a need to improve awareness-raising activities, active search, and broader tobacco treatment strategies 
among men. The mean age (50.6 years) shows a predominantly middle-aged population in groups. Literature data indicate that tobacco use usually begins in adolescence, on average, between 13 and 14 years old 11 . Few young people joined this strategy and sought treatment. This may indicate that it is necessary to invest in more youth-oriented policies, both for treatment and prevention, aiming to a more vulnerable population, with possibility of greater preventive effect on comorbidities by reducing exposure time and smoking load. As the activity was always carried out during the opening hours of the health care units (08a.m. - 06p.m.), it was highly likely that seniors, retired individuals, beneficiaries or people without a definite occupation participated. Formal workers have difficulty to leave work during working hours, thus they could not attend or missed sessions more often. Being absent once a week, for at least four weeks, is considerable absenteeism. The discussion about extending group meeting hours, using reverse shifts and focusing on this population, should be on the agenda of health services.

Considering that the professionals were offered minimum training in motivational interviewing (only eight hours), in addition to some degree of heterogeneity between teams and professionals, more intensive or recurrent training may be necessary. The GHC health teams are composed of different professionals, with diverse backgrounds. Despite the same recommendations as those of INCA being followed and the existence of coordination in the service and cohesion between teams, there may be some local differences in the way anti-tobacco program is conducted in each center. It is assumed that possible differences in the way of accessing the information system and collecting data may represent a limitation to the results. The professionals who coordinate the groups have differences as to their background and, according to their team, consist of family physicians, dentists, nurses, social workers, among others, assisted by community agents. Previous experiences as well as the possibly diverse way of incorporating the techniques from training and applying the elements of motivational interviewing, may somehow pose a limitation.

Note that this study evaluated abstinence rates at the end of the fourth weekly session of the smoking groups, that is, there was no long-term follow-up of the patients. Therefore, it was not possible to evaluate how lasting the intervention effect was on the time of abstinence and the frequency of relapses following the experiment. The evidence about this is scarce. In this respect, further studies able to measure the medium and long-term efficacy of motivational inteviewing are necessary, which will certainly add new evidence about its use. In light of these questions, the need for further studies within primary care, with larger samples and longer observation periods, and focusing specifically on the treatment strategy of tobacco use by groups, with evaluation and proof of cost-effectiveness, is reaffirmed. Thus, the real magnitude and size of the effect of using motivational interviewing in this setting can be more safely evaluated, and it will be possible to generalize it to other primary care contexts, adopting this as an effective treatment alternative for tobacco-dependent patients.

As a limitation of the study, it should be pointed out that the professionals in the control group did not receive any type of retraining or training due to the study. On the other hand, the professionals in the test group received training in the use of motivational interviewing, which can generate a Hawthorne effect. Another limitation was not having evaluated the patients' previous motivation level for smoking cessation. Since motivational interviewing is an approach designed to increase motivation, it seems reasonable to assume that it can work best on unmotivated participants. It is likely that people who participate in primary care cessation treatment are motivated to stop, it is possible that the results will be different in a less motivated population.

In conclusion, the study showed a statistically significant association between the use of motivational interviewing associated with CBT and better smoking cessation outcomes, increasing abstinence rates by $25 \%$, when compared to CBT alone used in groups by the SSC-GHC primary care teams. As this is an approach that can be easily used in primary care and other levels of care, with positive evidence of its effectiveness, it is a very useful strategy suited to tobacco control challenges in the SUS and public health. 


\section{Conclusion}

Motivational interviewing associated with the cognitive behavioral therapy was shown to be effective and superior to only the cognitive behavioral therapy to smoking cessation in groups in the fourth weekly session and for the population profile of the study (women with an average age of 50.6 years). This is a viable and appropriate behavioral approach to manage smoking in primary healthcare.

\section{Contributors}

R. Melnick and D. D. Faustino-Silva contributed to the study conception and design; data acquisition, analysis, and interpretation; drafting the article and critically reviewing for significant intellectual content; agreement to be accountable for all aspects of the work. C. S. Mendonça contributed to the drafting of the article and critically reviewing it for significant intellectual content. E. Meyer contributed to the study conception and design, analysis, and interpretation; drafting the article and critically reviewing it for significant intellectual content.

\section{Additional informations}

ORCID: Ricardo Melnick (0000-0003-3992-4916); Claunara Schilling Mendonça (0000-0001-62645769); Elisabeth Meyer (0000-0001-8642-037X); Daniel Demétrio Faustino-Silva (0000-0001-68766537).

\section{Conflict of interests}

The authors declare no conflicts of interest.

\section{Acknowledgments}

To the Community Health Service, Conceição Hospital Group for supporting the study and to Vania Naomi Hirakata for her statistical advice.

\section{References}

1. World Health Organization. Who Report on the Global Tobacco Epidemic, 2011: warning about the dangers of tobacco. Geneva: World Health Organization; 2011.

2. World Health Organization. Global status report on noncommunicable diseases 2014. Geneva: World Health Organization; 2014.

3. Schmidt MI, Duncan BB, Azevedo e Silva G, Menezes AM, Monteiro CA, Barreto SM, et al. Chronic non-communicable diseases in Brazil: burden and current challenges. Lancet 2011; 377:1949-61.

4. Departamento de Vigilância de Doenças e Agravos não Transmissíveis e Promoção da Saúde, Secretaria de Vigilância em Saúde, Ministério da Saúde. Vigitel Brasil 2013: vigilância de fatores de risco e proteção para doenças crônicas por inquérito telefônico. Brasília: Ministério da Saúde; 2014.

5. Departamento de Vigilância de Doenças e Agravos não Transmissíveis e Promoção da Saúde, Secretaria de Vigilância em Saúde, Ministério da Saúde. Vigitel Brasil 2016: vigilância de fatores de risco e proteção para doenças crônicas por inquérito telefônico. Estimativas sobre frequência e distribuição sociodemográfica de fatores de risco e proteção para doenças crônicas nas capitais dos 26 estados brasileiros e no Distrito Federal em 2016. Brasília: Ministério da Saúde; 2017.

6. Departamento de Atenção Básica, Secretaria de Atenção à Saúde, Ministério da Saúde. Estratégias para o cuidado da pessoa com doença crônica: o cuidado da pessoa tabagista. Brasília: Ministério da Saúde; 2015. (Cadernos de Atenção Básica, 40).

7. Cavalcante TM. O controle do tabagismo no Brasil: avanços e desafios. Rev Psiq Clín 2005; 32:283-300. 
8. Van Schayck OCP, Williams S, Barchilon V, Baxter N, Jawad M, Katsaounou PA, et al. Treating tobacco dependence: guidance for primary care on life-saving interventions. Position statement of the IPCRG. NPJ Prim Care Respir Med 2017; 27:38

9. Instituto Nacional de Câncer. Abordagem e tratamento do fumante: consenso 2001. Rio de Janeiro: Instituto Nacional de Câncer; 2001.

10. Bianchini IM, Glasenapp R. Tabagismo e hipertensão arterial sistêmica: recomendações para o trabalho de equipes da atenção primária à saúde Gerência de Saúde Comunitária. In: Ferreira SRS, Bianchini IM, Flores R, organizadores. A organização do cuidado às pessoas com hipertensão arterial sistêmica em serviços de atenção primária à saúde. Porto Alegre: Hospital Nossa Senhora da Conceição; 2011. p. 127-58.

11. Associação Médica Brasileira. Tabagismo: diretrizes clínicas. São Paulo: Associação Médica Brasileira; 2011.

12. Reichert J, Araújo AJ, Gonçalves CMC, Godoy I, Chatkin JM, Sales MPU, et al. Diretrizes para cessação do tabagismo: 2008. J Bras Pneumol 2008; 34:845-80.

13. Mesquita AA. Avaliação e tratamento psicológico do fumante: uma revisão bibliográfica. Mudanças: Psicologia da Saúde 2014; 22:3341.

14. Copeland AL. Characteristics of participants enrolled in a brief motivational enhancement for smokers. Front Psychiatry 2016; 2:77.

15. Rollnick S, Miller WR, Butler CC. Entrevista motivacional: ajudando pacientes a mudar o comportamento. Porto Alegre: Artmed; 2009.

16. Melo WV, Oliveira MS, Araujo RB, Pedroso RS. A entrevista motivacional em tabagistas: uma revisão teórica. Rev Psiquiatr Rio Gd Sul 2008; 30(1 Suppl).

17. Santos MDV, Santos ST, Caccia-Bava MCGG. Prevalência de estratégias para cessação do uso do tabaco na atenção primária à saúde: uma revisão integrativa. Ciênc Saúde Colet 2019; 24:563-72.

18. Mattos LR, Abreu AMM, Portela LF, Jomar RT, Paixão LAR. Cessação do tabagismo entre usuários da Estratégia Saúde da Família. Rev Enferm UERJ 2019; 27:e38987.

19. Gerência de Saúde Comunitária, Grupo Hospitalar Conceição. Indicadores de saúde: relatório anual 2014. Porto Alegre: Hospital Nossa Senhora da Conceição; 2015.
20. Gerência de Saúde Comunitária, Grupo Hospitalar Conceição. Sistema de informações em saúde do Serviço de Saúde Comunitária (SIS-SSC/GHC). Boletim informativo mensal: indicadores de saúde. Porto Alegre: Hospital Nossa Senhora da Conceição; 2015.

21. Miller WR, Yahne CE, Moyers TB, Martinez J, Pirritano M. A randomized trial of methods to help clinicians learn motivational interviewing. J Consult Clin Psychol 2004; 72:1050-62.

22. Silva EM. Efeitos da entrevista motivacional e do mapeamento cognitivo associados à TCCG no tratamento de pacientes com transtorno obsessivo-compulsivo [Tese de Doutorado]. Porto Alegre: Universidade Federal do Rio Grande do Sul; 2009.

23. Miller WR, Rollnick S. Motivational Interviewing: helping people change. 3rd Ed. New York: The Guilford Press; 2013.

24. Miller WR, Hedrick KE, Orlofsky D. The helpful responses questionnaire: a procedure for measuring therapeutic empathy. J ClinPsychol $1991 ; 47: 444-8$.

25. Lindson N, Thompson TP, Ferrey A, Lambert JD, Aveyard P. Motivational interviewing for smoking cessation. Cochrane Database Syst Rev 2019; (7):CD006936.

26. Catley D, Goggin K, Harris KJ, Richter KP, Williams K, Patten C, et al. A randomized trial of motivational interviewing cessation induction among smokers with low desire to quit. Am J Prev Med 2016; 50:573-83.

27. Butler CC, Rollnick S, Cohen D, Bachmann M, Russell I, Stott N. Motivational consulting versus brief advice for smokers in general practice: a randomized trial. Br J Gen Pract 1999; 49:611-6.

28. Heckman CJ, Egleston BL, Hofmann MT. Efficacy of motivational interviewing for smoking cessation: a systematic review and metaanalysis. Tob Control 2010; 19:410-6.

29. Vanbuskirk KA, Whterell J. Motivational interviewing used in primary care a systematic review and meta-analysis A. J Behav Med 2014; 37:768-80.

30. Figlie NB, Guimarães LP. A entrevista motivacional: conversas sobre mudança. Boletim Academia Paulista de Psicologia 2014; 34:47289. 


\section{Resumo}

O tabagismo é a principal causa de morte evitável, e é um problema de saúde pública global. A atenção primária representa um contexto estratégico para enfrentar o problema. O objetivo foi avaliar a efetividade da entrevista motivacional associada à terapia cognitiva-comportamental (TCC) em grupos de tabagistas tratados na atenção primária. Foi realizado um estudo clínico randomizado de clusters comunitários, iniciado em julho de 2016. Os profissionais no grupo experimental foram treinados durante 8 horas na técnica de entrevista motivacional, com o propósito de associar a técnica à TCC. O tratamento usual para cessação de tabagismo em grupos consiste em quatro sessões estruturadas com duração de 90 minutos, uma por semana, com o uso da TCC. Foi aplicada a linearização de Taylor para corrigir os valores de p; o teste qui-quadrado de Pearson foi usado para variáveis categóricas e análise de variância, e o teste $t$ de Student para variáveis contínuas. Foram organizados 44 grupos de tabagistas, com um total de 329 pacientes (178 no grupo entrevista motivacional e 151 no grupo controle). A taxa de cessação do tabagismo com entrevista motivacional foi 61,8\%, com $R R=1,25$ (IC95\%: 1,01-1,54; $p=0,043)$, comparado com $47,7 \%$ no grupo controle, depois da quarta sessão semanal de terapia de grupo. A média de frequência foi de 3,1 sessões (IC95\%: 2,9-3,3) no grupo entrevista motivacional e 2,9 (IC95\%: 2,5-3,4) no grupo controle. A proporção de participação integral nas sessões foi $65,2 \%$ no gruo entrevista motivacional e 57,6\% no grupo controle. A entrevista motivacional associada à TCC mostrou ser efetiva e superior à TCC isoladamente para cessação de tabagismo em grupos com quatro sessões semanais e para o perfil da população do estudo (mulheres com média de idade de 50,6 anos).

Fumar; Entrevista Motivacional; Abandono do Hábito de Fumar; Atenção Primária à Saúde; Avaliação da Tecnologia Biomédica

\section{Resumen}

Fumar es la principal causa de muerte evitable, y uno de los mayores problemas de salud pública alrededor del mundo, siendo la atención primaria un eje estratégico para el tratamiento de este problema. El objetivo fue evaluar la efectividad de las entrevistas motivacionales, asociadas con la terapia comportamental cognitiva (TCC), en grupos de fumadores dentro de la atención primaria. El ensayo clínico grupal aleatorio basado en comunidades se realizó en Brasil, empezó en julio de 2016. Los profesionales en el grupo de prueba fueron entrenados en entrevistas motivacionales durante 8 horas para asociarlo con el TCC. El tratamiento habitual para dejar de fumar en grupos consistía en cuatro sesiones semanales, estructuradas en 90 minutos cada una, usando la TCC. Se aplicó la linealización de Taylor para corregir los valores de p; el test de chi-cuadrado con la correlación de Pearson se usó para las variables categóricas y se utilizaron el análisis de variancia y el test Student t para las variables continuas. Se monitorizaron 44 grupos de fumadores, totalizando 329 pacientes (178 en el entrevistas motivacionales grupo y 151 en el grupo de control). La tasa de abandono del tabaco con entrevistas motivacionales fue $61,8 \%$, con $R R=1,25$ (95\%CI: 1,01-1,54; $p=0,043$ ), $y$ $47,7 \%$ en el grupo de control, en la cuarta sesión grupal de tratamiento semanal. La media de asistencia a sesiones fue 3,1 (95\% CI: 2,9-3,3) en el grupo entrevistas motivacionales y 2,9 (95\% CI: 2,5-3,4) en el grupo de control. La tasa de finalización para el grupo entrevistas motivacionales fue $65,2 \%$, y para el grupo de control 57,6\%. Las entrevistas motivacionales asociadas con la TCC demostró ser efectiva y superior para solamente la TCC de abandonar el tabaco en grupos en la cuarta sesión semanal y para el perfil de la población en estudio (mujeres con una media de edad de 50,6 años).

Fumar; Entrevista Motivacional; Cese del Hábito de Fumar; Atención Primaria de Salud; Evaluación de la Tecnología Biomédica
Submitted on 09/Mar/2020

Final version resubmitted on 23/Jun/2020

Approved on 17/Jul/2020 